\title{
Genetics and Epigenetics of One-Carbon Metabolism Pathway in Autism Spectrum Disorder: A Sex-Specific Brain Epigenome?
}

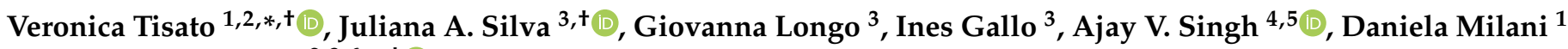 \\ and Donato Gemmati $2,3,6, *,+$ (D) \\ 1 Department of Translational Medicine and LTTA Centre, University of Ferrara, 44121 Ferrara, Italy; \\ daniela.milani@unife.it \\ 2 University Center for Studies on Gender Medicine, University of Ferrara, 44121 Ferrara, Italy \\ 3 Department of Translational Medicine, University of Ferrara, 44121 Ferrara, Italy; slvjln@unife.it (J.A.S.); \\ giovanna.longo@unife.it (G.L.); ines.gallo@unife.it (I.G.) \\ 4 Physical Intelligence Department, Max Planck Institute for Intelligent Systems, 70569 Stuttgart, Germany; \\ Ajay-Vikram.Singh@bfr.bund.de \\ 5 Department of Chemical and Product Safety German Federal Institute (BfR), Max-Dohrnstr 8-10, \\ 10589 Berlin, Germany \\ 6 Centre of Hemostasis \& Thrombosis, University of Ferrara, 44121 Ferrara, Italy \\ * Correspondence: veronica.tisato@unife.it (V.T.); d.gemmati@unife.it (D.G.) \\ + Equally contributed.
}

check for updates

Citation: Tisato, V.; Silva, J.A.; Longo, G.; Gallo, I.; Singh, A.V.; Milani, D.;

Gemmati, D. Genetics and

Epigenetics of One-Carbon

Metabolism Pathway in Autism Spectrum Disorder: A Sex-Specific Brain Epigenome? Genes 2021, 12, 782. https://doi.org/10.3390/ genes12050782

Academic Editor: Zeynep HTümer

Received: 26 March 2021

Accepted: 17 May 2021

Published: 20 May 2021

Publisher's Note: MDPI stays neutral with regard to jurisdictional claims in published maps and institutional affiliations.

Copyright: (c) 2021 by the authors. Licensee MDPI, Basel, Switzerland. This article is an open access article distributed under the terms and conditions of the Creative Commons Attribution (CC BY) license (https:// creativecommons.org/licenses/by/ $4.0 /)$.

\begin{abstract}
Autism spectrum disorder (ASD) is a complex neurodevelopmental condition affecting behavior and communication, presenting with extremely different clinical phenotypes and features. ASD etiology is composite and multifaceted with several causes and risk factors responsible for different individual disease pathophysiological processes and clinical phenotypes. From a genetic and epigenetic side, several candidate genes have been reported as potentially linked to ASD, which can be detected in about $10-25 \%$ of patients. Folate gene polymorphisms have been previously associated with other psychiatric and neurodegenerative diseases, mainly focused on gene variants in the DHFR gene (5q14.1; rs70991108, 19bp ins/del), MTHFR gene (1p36.22; rs1801133, C677T and rs1801131, A1298C), and CBS gene (21q22.3; rs876657421, 844ins68). Of note, their roles have been scarcely investigated from a sex/gender viewpoint, though ASD is characterized by a strong sex gap in onsetrisk and progression. The aim of the present review is to point out the molecular mechanisms related to intracellular folate recycling affecting in turn remethylation and transsulfuration pathways having potential effects on ASD. Brain epigenome during fetal life necessarily reflects the sex-dependent different imprint of the genome-environment interactions which effects are difficult to decrypt. We here will focus on the DHFR, MTHFR and CBS gene-triad by dissecting their roles in a sex-oriented view, primarily to bring new perspectives in ASD epigenetics.
\end{abstract}

Keywords: brain-epigenome; one-carbon metabolism genes; folate; SNPs; gene variants; epigenetics; autism spectrum disorder (ASD); sex-gap; gender-gap

\section{Introduction}

In 1943, Kanner was the first to systematically define autism as an innate inability to create normal, biologically determined, and emotional contact with others [1]. Currently, autistic disorder, along with pervasive developmental disorder not otherwise specified (PDD-NOS), and Asperger syndrome represent the complex set of human neurodevelopmental diseases collectively known as autism spectrum disorder (ASD) [2]. Although potentially diagnosed at any age, autism has an early age of onset with more than $1 \%$ of affected children characterized by a wide range of severity and continuous distribution of ASD traits in the general population [3]. ASD patients typically experience difficulty with social communication and interaction, restricted interests, and repetitive behaviors [4]. Indeed, despite the available technological advances and the innovative experimental 
approach of study, there is still not a definite and direct causal relationship or pattern to completely understand the pathogenesis of this complex disorder [5].

On the other hand, there is evidence for specific features in common with other diseases such as immune dysregulation and inflammation characterized by higher proinflammatory cytokines (mirror of neuroinflammation), oxidative stress inception and mitochondrial dysfunction as well as dysfunctions of other organs than the brain (e.g., gastrointestinal disorders) [6-8]. Although it is not clear whether to consider them as disease-causative events, or mere consequence of other etiological processes, they are under investigation as potential targets for ASD treatment [8-10].

ASD has a strong heritable component making it essentially a genome-based human disease [11]. It has been reported indeed that monozygotic twins have around a $90 \%$ chance of sharing the disease, while dizygotic twins have only a $5 \%$ to $10 \%$ risk of comorbidity [12]. Besides that, Fragile X Syndrome (FXS) is reported as the most common $\mathrm{X}$-linked monogenic cause of Intellectual Disability (ID) or ASD, and rare or common gene variants, as well as particular gene deletions in the mother's genome, might contribute to ASD development [13]. Together with recognized gene-linked syndromes, several ASD patients show chromosomal rearrangements [14], with a crucial time point for damageonset identified during embryogenesis at the stage of neural tube closure [15]. Of note, this event has been hypothesized to have sex-related differences due to the role of specific genes (i.e., SOX9) in affecting male phenotype development and skeletal growth [16,17]. So far, incomplete penetrance has been observed and no causative specific gene has been definitely demonstrated to be the primary ASD contributor [13].

GWAS are now bridging the gap in knowledge existing between ASD and other neurodevelopmental/neuropsychiatric disorders, with the latter being more extensively investigated. Accordingly, the existence of 12 independent loci significantly associated with attention-deficit/hyperactivity disorder (ADHD), a neurodevelopmental psychiatric disorder overlapping ASD, has been reported also highlighting the key role of GWAS in discovering common gene variants $[18,19]$. Moreover, additional common risk gene variants have been identified as significantly associated with ASD, mainly related to neuronal function and corticogenesis, as well as genetic correlations with other complex disorders and traits in line with a common etiology of the different pathology [20]. Of note, different ASD clinical phenotypes are characterized by complex polygenic architectures and organization [20]. Finally, in the recently published largest ASD exome sequencing study, 102 risk genes have been associated with brain development and regulation of gene expression and neuronal communication [19].

In terms of ASD risk factors definition, there is unanimous agreement on the multifactorial framework of the etiology, suggesting that in most cases autism results from the interaction of multiple genetic and environmental factors, as often demonstrated for other complex diseases [21-27]. In this line, the role and interplay between genetics and environment with effects on epigenetics and epigenomics have become the subject of intensified researches $[5,28,29]$. Hypotheses have been attempted to explain the environmental components of ASD, including aspects related to diet and to nutritional epigenetics [30], economic status, vaccination, general health, environmental pollutants, gut, oral and vaginal microbiomes, the latter indicating potential in utero etiopathology of ASD during pregnancy [5,31-33]. Overall, despite the several hypotheses, the precise role of genetic and environmental factors in determining the individual risk and disease phenotype still needs to be fully clarified.

Among those genes associated with modification of disease susceptibility, the ones belonging to the folate homeostasis and methionine-homocysteine recycling are gaining interest in the context of different neuropsychiatric/neurobehavioral disorders [34,35]. In the past decades, several studies indicated that low folate levels and vitamin B12 together with high homocysteine (Hcy) levels were associated with neurodevelopmental disease, especially cognitive decline in psychogeriatric and psychiatric patients [36]. This condition may be exacerbated by the presence of specific gene polymorphisms of the folate pathway 
that drive folate isoforms cycling and balance [37]. In this line, a personalized folic acid supplementation during pregnancy based on the genetic assessment of pregnant women should be considered [37].

Overall, the gene-triad belonging to the remethylation and transsulfuration pathways are dihydrofolate reductase (DHFR), methylenetetrahydrofolate reductase (MTHFR), and cystathionine- $\beta$ synthase (CBS) are potential candidates as modifier genes in ASD susceptibility.

\section{One-Carbon Metabolism Pathway}

One-carbon metabolism is crucial in epigenetic regulation during embryo development and it is an integrated complex system composed of three main pathways: the folate cycle, the methionine cycle, and the transsulfuration pathway [38]. Folate belongs to the B-vitamins family (B9); it can be obtained from nutritional sources (e.g., leafy greens, beans, vegetables, seeds/legumes) or by supplementation in the form of folic acid. Folate is considered a key factor during neurodevelopment, its deficit associated with neural tube defects (NTD) have led in the recent past to extensive fortification protocols in several countries [39]. Dietary folate is absorbed at the intestinal level by the proton-coupled folate transporter (PCFT) and the reduced folate carrier (RFC), shuttled to the liver via hepatic portal vein followed by hepatocytes uptake. When secreted in blood circulation, folate can reach several tissues and undergo cellular uptake by means of three folate receptors (FR) the GPI-anchored cell membrane FR $\alpha$ and FR $\beta$, and the secreted form FR $\gamma$ [40]. The receptors are differentially expressed in the different tissues, although FR $\alpha$ plays the main role in cellular uptake [40]. Once in the cells, reduced folate isoforms act as cofactors in the one-carbon units metabolism [41,42]. Importantly, as they serve as onecarbon carriers for methyl group transfer to cytosine residues of $\mathrm{CpGs}$ promoter regions in genomic DNA, folate has key roles in DNA synthesis/repair, in purines/pyrimidines synthesis, aminoacid synthesis as well as in DNA/histone methylation, the latter being one of the main epigenetic processes able to change/affect gene expression in both healthy and disease conditions [43-45]. Overall, folate is crucial during neurodevelopment and it represents an efficient mediator of the crosstalk between genetics and epigenetics [40,46]. Deficiencies or unbalancing of the mutual levels of the different intracellular folate isoforms may negatively act during fetal growth and promote pediatric cancers, leukemia, neurodevelopmental disorders [47-51].

Folate biochemistry has been deeply investigated in the past [43]. Briefly, once in the cells, folate is converted into its tetrahydrofolate (THF) active form by a two-step process dependent on NADPH and DHFR. As shown in Figure 1, 5,10-methylene-THF can be converted to 5-methyl-THF by the MTHFR enzyme and recycled back to THF by methionine synthase (MS). 5-methyl-THF may transfer its methyl group to cobalamin (B12) and the resulting methyl-cobalamin can act as a methyl-donor for Hcy to generate MS-mediated methionine. Finally, the irreversible degradation of Hcy takes place by the transsulfuration pathway via sulfur transfer from Hcy to cysteine by CBS enzyme, considered as the only way for cysteine synthesis [52] a potent component of antioxidant glutathione [53]. 


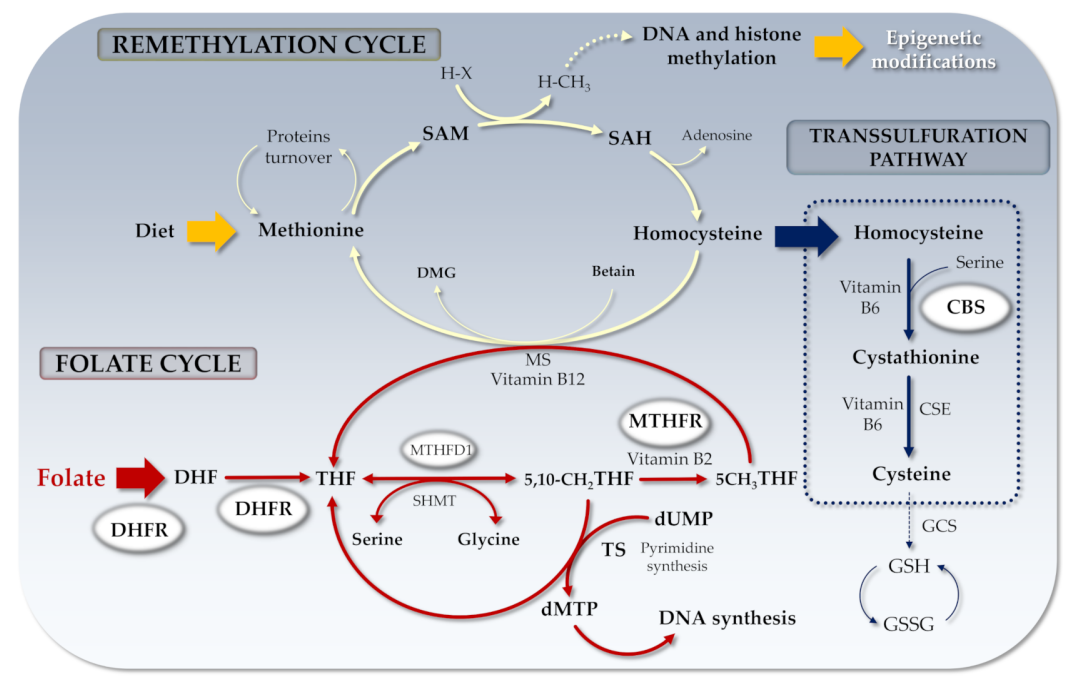

Figure 1. Folate cycle and related genes. DHF: Dihydrofolate; THF: Tetrahydrofolate; SAM: Sadenosyl methionine; SAH: S-adenosyl Homocysteine; MTHFR: Methylenetetrahydrofolate reductase; RCF: Reduced folate carrier; DHFR: Dihydrofolate reductase; dUMP: Uridine monophosphate; dTMP: Thymidine monophosphate; DMG: Dimethylglycine; MS: Methionine synthase; CBS: Cystathionine- $\beta$-synthase; $\mathrm{H}-\mathrm{X}$ : Methyl acceptor; $\mathrm{H}-\mathrm{CH}_{3}$ : Methylated acceptor; TS: Thymidylate synthase; MTHFD1: Methylenetetrahydrofolate dehydrogenase-1 (NADP+ dependent); CSE: Cystathionine $\gamma$-lyase; GCS: $\gamma$-glutamylcysteine synthetase; GSH: Glutathione; GSSG: Glutathione disulfide.

Males typically show higher Hcy circulating levels compared to females (about 10-15\% higher), though the sex gap is normally reduced by women menopause transition. Folate deficiency is associated with hyperhomocysteinemia, a recognized risk factor for several pathological conditions, with a strong inverse relation driven by the number of variant alleles in the MTHFR gene [43,49]. In a recent study performed in Israel where no national folic acid fortification programs exist, males, as expected, showed the lowest folate levels compared to females [54]. The consequence of low folate on Hcy levels was that males had higher Hcy than females also in presence of normal B12 levels and independently from age and estrogen effect [54].

Potential explanations may be due to sex-related differences in the prevalence and effects of polymorphic gene variants [55]. Accordingly, anomalous transsulfuration pathway and dysregulated folate or Hcy metabolism may lead to aberrant redox homeostasis and neurodegeneration, and in turn, increased ASD susceptibility [56-58]. Several studies have indeed reported a correlation between high Hcy and low folate, vitamin B6, and B12 levels with ASD and severity [58,59]. Of note, gastrointestinal disorders experienced by ASD children may be also due to insufficient intake of B-family vitamins responsible for increased circulating Hcy [60]. As a proof of concept of the proposed link, folate supplementation would result in improved clinical symptoms in ASD patients [61], in reducing Hcy levels, and in glutathione metabolism optimization [62,63].

Changes in levels of metabolites belonging to the methionine and folate cycle can be considered epigenetic predictive biomarkers for ASD as well as potential therapeutic targets though correlations with ASD etiology/severity still need to be defined [64,65]. Overall, in a future perspective, mother-child genomes and epigenetics interactions might become new targets for innovative therapeutic interventions.

\subsection{MTHFR Gene and Functions}

MTHFR gene is located on chromosome 1 (1p36.22), it comprises 12 exons and encodes for a protein product of 697aa [66]. Within the folate cycle, the MTHFR enzyme catalyzes the synthesis of the active folate isoform (i.e., 5-methyl-THF) efficiently involved in DNA synthesis and methylation processes [43,51]. MTHFR gene defects and variants have been associated with an array of complex neurological conditions $[67,68]$. 
The main investigated and clinically effective MTHFR single nucleotide polymorphisms (SNP) are the C677T transition (rs1801133) and the A1298C transversion (rs1801131). There is an estimate that more than $60 \%$ of the general population carries one of the two polymorphic alleles, and at least $10 \%$ of them carries both the alleles being homozygotes (677TT or 1298CC) and/or compound heterozygotes rarely in cis (CT/AC) more frequently in trans (CT/CA) in consideration of the strong linkage disequilibrium [69].

MTHFR C677T variant is due to a cytosine change in thymine at position 677 of exon 4 leading to the replacement of an alanine by a valine (A223V) resulting in a thermolabile enzyme with reduced enzyme activity which is particularly marked in folate deficient conditions $[49,69]$. There exists a strong direct correlation between folate availability and Hcy levels by distinct MTHFR genotypes both in normal and case patients [43,49]. For instance, the homozygous C677T (TT) condition is associated with increased Hcy and lower folate levels [31]. Accordingly, maternal folate status, mainly driven by interactions between specific genetic backgrounds and diet, is of particular relevance during pregnancy since it may favor ASD susceptibility [70,71].

MTHFR A1298C variant is due to an adenine change in a cytosine at position 1298 of exon 7 leading to the replacement of glutamic acid by an alanine (E429A) resulting in an enzyme with reduced activity more detrimental in the homozygous 1298CC condition though at a lesser extent than the C677T [72,73]. The association of A1298C with NTD and mental illness seems almost controversial [67]. One possible explanation for such diverse findings is that the risk for NTD might depend on the combined gene polymorphisms and/or additional genes and variants also influenced by nutritional factors [69,74].

Combined heterozygosity of the two MTHFR variants leads to lower MTHFR enzyme activity than the two single heterozygosity separately and causes high Hcy and low folate levels to an extent comparable to 677TT homozygotes [75]. MTHFR 677T/1298C cishaplotype is a rare condition and it has been more frequently observed among spontaneous abortions than in healthy neonates suggesting strong unfavorable effects $[76,77]$.

A previous meta-analysis reported a weak correlation between MTHFR C677T polymorphism, depression, and anxiety in children and adults by studying 1,119 cases of schizophrenia and 1,308 controls reporting that 677TT genotype had the greatest risk of schizophrenia (OR =1.48; CI 95\%, 1.18-1.86), compared to subjects with CC and CT genotype combined [78]. In the same study by comparing the CT genotype with CC homozygotes no significant risk association was found (OR = 1.04; CI 95\%, 0.87-1.25) [78].

The finding that sex and age differently influence folate and Hcy levels and in turn cell specific methylation status ascribes to MTHFR genotypes a potential role on various psychiatric disorders [79]. Similarly, sex hormones show targeted effects on psychiatric disorders with a protective role of estrogen on neurodevelopment and social maturation in schizophrenia while testosterone increases male vulnerability due to its unfavorable effect on neurotransmitters regulation $[79,80]$.

The role of MTHFR in ASD has been less investigated compared with other mental illnesses, such as schizophrenia and depression, though several reports highlighted a potential role of C677T and A1298C variants in ASD risk establishment (Table 1). Interestingly, MTHFR polymorphisms and folate status might be involved in the early phase of ASD establishment during pregnancy, as reported in both preclinical setting [80] and clinical studies (Table 1). Of interest, studies on mother-child dyads strongly support the crucial role of the crosstalk between mother/child gene landscapes and circumstantial conditions such as perinatal intake of folate supplement in different ethnicities. In particular, in the CHARGE study, a correlation between mother/child genotypes of one-carbon metabolism genes and periconceptional vitamins intake has been reported in ASD [81]. The authors highlight higher frequencies of 677TT homozygosis in ASD children than in healthy controls, and the mothers of ASD children carrying TT-genotype less likely had prenatal vitamins intake [71,81].

Although C677T transition was more frequently reported as potentially involved in ASD risk establishment, synergic effects also emerged between the two MTHFR SNPs 
(Table 1) and the reported results are encouraging, though the precise role of C677T and A1298C in ASD is still almost controversial [82]. Of note, a clinical application of genetic testing in autism has been recently attempted in a two-year-old boy at high risk of autism in which MTHFR genetic screening allowed an early therapeutic folate supplementation as a conventional therapeutic regimen. This approach led to a significant clinical recovery, supporting an effective pharmacogenetics approach in such a complex disease [83].

Table 1. Selected Studies on MTHFR, DHFR and CBS Genes Reporting Significant Associations with ASD.

\begin{tabular}{|c|c|c|c|}
\hline Gene & Key Findings & Genotype/Allele & Ref \\
\hline MTHFR & $\begin{array}{l}\text { - Increased frequency of MTHFR C677T in ASD } \\
\text { - Unexpected high frequency of the normal MTHFR } \\
\text { 1298AA genotype in ASD } \\
\text { - Combined MTHFR 677CT/1298AC haplotype more } \\
\text { prevalent in ASD }\end{array}$ & $\begin{array}{l}677 \mathrm{CT} / \mathrm{TT} \\
1298 \mathrm{AA}\end{array}$ & [84] \\
\hline MTHFR & $\begin{array}{l}\text { - Circulating methionine and SAM/SAH ratio are } \\
\text { significantly decreased in ASD } \\
\text { - Circulating cysteine, GSH, and GSH/GSSG ratio are } \\
\text { significantly decreased in ASD } \\
\text { - Disease association with MTHFR C677T and A1298C }\end{array}$ & $\begin{array}{l}677 \text { CT+TT } \\
\text { 1298/677 AC/CT combined } \\
\text { with RFC 80GA }\end{array}$ & [85] \\
\hline DHFR & $\begin{array}{l}\text { - DHFR } 19 \mathrm{bp} \text { ins / del is a risk factor for ASD } \\
\text { independently from and in association with folate } \\
\text { polymorphisms } \\
\text { - DHFR } 19 \mathrm{bp} \text { ins / del combined with MTHFR C677T } \\
\text { and A1298C }\end{array}$ & $\begin{array}{c}\text { 19bp del } \\
19 b p \text { del+677T+1298C }\end{array}$ & [86] \\
\hline MTHFR & $\begin{array}{l}\text { - } \quad \text { MTHFR C677T emerges as primary ASD risk factor } \\
\text { - } \quad \text { MTHFR A1298C emerges as additive risk factor for } \\
\text { ASD in combination to C677T }\end{array}$ & $\begin{array}{c}677 \mathrm{~T} \\
677 \mathrm{~T}+1298 \mathrm{C}\end{array}$ & [72] \\
\hline MTHFR & $\begin{array}{l}\text { - High frequency of MTHFR } 677 \text { T-allele and } \\
\text { TT-genotype, } 677 / 1298 \mathrm{~T} / \mathrm{A} \text { and TT/AA haplotypes in } \\
\text { ASD } \\
\text { - Preferential parental transmission of } 677 \mathrm{~T} \text { - and } 1298 \\
\text { A-allele or } 677 / 1298 \mathrm{~T} / \mathrm{A} \text { haplotypes in affected } \\
\text { offspring }\end{array}$ & $\begin{array}{c}677 \mathrm{~T} \\
1298 \mathrm{AA}\end{array}$ & [87] \\
\hline MTHFRCBS & $\begin{array}{l}\text { - Periconceptional vitamins intake reduces the risk of } \\
\text { having ASD children in genetically susceptible } \\
\text { mothers / children dyad } \\
\text { - Higher ASD risk in mother MTHFR 677TT, CBS } \\
\text { rs234715 GT+TT with child COMT } 472 \text { AA genotypes } \\
\text { - Higher ASD risk in mothers also carrying other } \\
\text { one-carbon metabolism gene variants }\end{array}$ & $\begin{array}{l}677 \text { TT combined with other } \\
\text { one-carbon gene variants, } \\
\text { both in mother and child }\end{array}$ & [81] \\
\hline MTHFR & $\begin{array}{l}\text { - Lower ASD risk associated to folic acid supplement } \\
\text { strongest in MTHFR C677T carriers (mothers/children) }\end{array}$ & $677 \mathrm{CT}+\mathrm{TT}$ & [88] \\
\hline MTHFR & $\begin{array}{l}\text { - High frequency of MTHFR 677TT in ASD children } \\
\text { - Over-activity significantly associated to MTHFR } \\
\text { 677TT genotype (Stratification by Autism Diagnostic } \\
\text { Interview) }\end{array}$ & $677 \mathrm{TT}$ & [89] \\
\hline MTHFR & $\begin{array}{l}\text { - Meta-analysis: eight case-control studies included } \\
\text { - Higher ASD risk to MTHFR C677T polymorphism } \\
\text { (all comparison models) } \\
\text { - Lower ASD risk to MTHFR A1298C polymorphism } \\
\text { (recessive model) } \\
\text { - ASD association to MTHFR C677T polymorphism } \\
\text { (only in countries without food fortification) }\end{array}$ & $\begin{array}{l}677 \mathrm{CT}+\mathrm{TT} \\
1298 \mathrm{CC}\end{array}$ & {$[71]$} \\
\hline
\end{tabular}


Table 1. Cont.

\begin{tabular}{|c|c|c|c|}
\hline Gene & Key Findings & Genotype/Allele & Ref \\
\hline MTHFR & $\begin{array}{l}\text { - } \text { Associations to ASD with MTHFR A1298C } \\
\text { - Higher ASD risk to MTHFR 677CT/1298AC } \\
\text { combined genotype } \\
\text { - } \quad \text { No significant associations in females }\end{array}$ & $\begin{array}{c}1298 \mathrm{AC}+\mathrm{CC} \\
677 / 1298 \mathrm{CT} / \mathrm{AC}\end{array}$ & [90] \\
\hline MTHFR & $\begin{array}{l}\text { - Meta-analysis: thirteen studies included ( } 9 \text { on } \\
\text { Caucasians, } 4 \text { on Asians) } \\
\text { - Significant association between ASD and MTHFR } \\
\text { C677T polymorphism }\end{array}$ & $\begin{array}{l}677 \mathrm{CT}+\mathrm{TT} \\
677 \mathrm{TT} \\
677 \mathrm{~T}\end{array}$ & [91] \\
\hline MTHFR & $\begin{array}{l}\text { - Higher MTHFR A1298C frequency in ASD (AC: } \\
\text { 41.9\%; CC: } 35.5 \% \text { ) } \\
\text { - Higher MTHFR C677T frequency in ASD (CT: } 48.4 \% \text {; } \\
\text { TT } 12.9 \%) \\
\text { - Heterozygosity was equally detected (46.2\%) among } \\
\text { patients with severe autism }\end{array}$ & $\begin{array}{l}677 \mathrm{CT}+\mathrm{TT} \\
677 \mathrm{~T} \\
1298 \mathrm{AC}+\mathrm{CC} \\
1298 \mathrm{C}\end{array}$ & [92] \\
\hline CBS & $\begin{array}{l}-\quad \text { Higher CBS C699T frequencies distributions (TT and } \\
\text { CT+TT) in ASD patients } \\
\text { - Lower CBS C699T frequency associated with sleep } \\
\text { and GIT disorders } \\
\text { - No significant association between CBS genotypes } \\
\text { and severity of ASD }\end{array}$ & $\begin{array}{c}699 \mathrm{CT}+\mathrm{TT} \\
699 \mathrm{TT}\end{array}$ & [93] \\
\hline MTHFR & $\begin{array}{l}\text { - Meta-analysis: } 25 \text { case-control studies on MTHFR } \\
\text { (C677T, } 18 \text { studies) (A1298C, } 7 \text { studies) } \\
\text { - Higher MTHFR C677T frequency in ASD } \\
\text { - No overall association between MTHFR A1298C and } \\
\text { ASD risk } \\
\text { MTHFR A1298C significantly associated only in } \\
\text { Caucasians }\end{array}$ & $\begin{array}{l}677 \mathrm{CT}+\mathrm{TT} \\
677 \mathrm{TT} \\
677 \mathrm{~T} \\
1298 \mathrm{CC} \\
1298 \mathrm{C}\end{array}$ & [94] \\
\hline MTHFR & $\begin{array}{l}\text { - Meta-analysis: } 15 \text { studies } \\
\text { - Higher ASD risk to MTHFR C677T polymorphism } \\
\text { (all comparison models) } \\
\text { - No association between MTHFR A1298C and ASD } \\
\text { (all comparison models) }\end{array}$ & $\begin{array}{l}677 \mathrm{CT}+\mathrm{TT} \\
677 \mathrm{TT} \\
677 \mathrm{~T} \\
677 / 1298 \mathrm{~T} / \mathrm{C}\end{array}$ & [95] \\
\hline DHFR & $\begin{array}{l}\text { - Positive association (not adjusted) between cord } \\
\text { total folate and UMFA also after DHFR genotype } \\
\text { stratification (limited to Black children) }\end{array}$ & 19bp del/del & [96] \\
\hline
\end{tabular}

Overall, it becomes clear that there is the need for additional genetics and epigenetics studies preferentially focused on the mother/child dyad genome comparison also considering the low number of ASD females included in the studies.

\subsection{DHFR Gene and Functions}

The DHFR gene is located on chromosome 5 (5q14.1); it comprises 6 exons and encodes for a protein product of 187 aa $[97,98]$. It functionally catalyzes the conversion of DHF into THF and folic acid into DHF and THF [99]. DHF and THF are the two key folate isoforms involved in the folate cycle and Hcy metabolism as well as in de novo synthesis of a variety of essential metabolites including amino acids, lipids, pyrimidines, and purines [68]. A different DHFR enzyme activity is decisive for the relative ratio between optimal DNA methylation and faithful DNA replication [43]. One of the main functional polymorphisms within DHFR gene is a 19-base pair insertion/deletion (19bp ins/del) (rs70991108) in the promoter/first intron of the gene [68,100], associated with a limited ability of the enzyme to convert THF into 5,10-methylene THF [68]. Alongside DHFR also holds additional important non-folate-related roles in converting dihydrobiopterin (BH2) to tetrahydrobiopterin (BH4) which is the co-factor for dopamine and serotonin enzymatic 
production [101]. Thus, downregulation of DHFR enzymatic activity leads to decreased BH4 levels and to an imbalanced BH4/BH2 ratio that is essential for NO-synthesis, inhibition of superoxide release from endothelial NO-synthase and other functions including tyrosine hydroxylase (involved in the production of 1-dopa), tryptophan hydroxylase and phenylalanine hydroxylase [101-103].

DHFR 19bp ins/del has been independently associated, alone or in combination with other folate related gene variants, with a significant risk for ASD, possibly by interactions between folate and the glutamatergic nervous system (Table 1) [86]. Folate isoforms conjugate indeed with glutamate residues, facilitating the excitatory properties of glutamate. For this reason, a dysregulated Hcy remethylation may affect the glutamatergic signaling since it acts as an endogenous agonist of a subgroup of excitatory glutamatergic receptors involved in the synaptic transmission. Therefore, dysregulated folate and glutamate homeostasis can be considered combined key factors in the occurrence of ASD. Accordingly, the Autism Genome Project Consortium published in the past a study on autism risk loci. The Consortium considered the glutamate-related genes as promising candidates in ASD since glutamate pathway has a key role in neuronal plasticity and development suggesting that ASD could be considered a glutamatergic system disorder [104].

Of note, the use of DHFR inhibitors in oncologic children points out great concerns due to potential long-term side effects. In detail, the folate antagonist methotrexate, by lowering THF availability and in turn pyrimidine and purines production as well as RNA and DNA synthesis, has been associated with decreased volume of subcortical structures, cognitive impairment and increased prevalence of autistic-like symptoms among methotrexate treated children $[105,106]$.

It has been also reported that folic acid supplements might saturate DHFR enzyme in the liver of humans, and then slow down the conversion of folic acid to THF taking up to 12 $\mathrm{h}$ for a single $5 \mathrm{mg}$ dose of folic acid in selected individuals carrying susceptible haplotypes, suggesting caution regarding over-supplementation $[107,108]$. Concern has been expressed particularly about unmetabolized folic acid (UMFA) that may be detrimental in the presence of specific haplotypes, particularly in pregnant women carrying selected folate gene variants [109]. In fact, during pregnancy, unbalanced folate isoforms distribution may drive and favor aberrant epigenetic mechanisms on the offspring, and nonetheless, maternal folate supplementation efficiently reduces congenital malformations as NTD or cleft palate, indiscriminate fortification may cause severe pediatric pathological conditions [109,110]. A suboptimal conversion of folic acid into active folate, as in presence of particular DHFR and MTHFR gene variants, reduces UMFA-threshold particularly during critical conditions such as pregnancy, exacerbating negative side effects and concerns, suggesting a a safe supplementation assessed by pharmacogenetics investigations $[108,111]$.

In the context of ASD, DHFR 19bp ins/del has been suggested as an inherited modifying factor during pregnancy, mainly due to an unusual DHFR activity associated with unmetabolized pteroylmonoglutamate (i.e., therapeutic folate) during the embryogenesis process by accumulation in the central nervous system [109]. Accordingly, a positive correlation has been found between MTHFR C677T and DHFR 19bp ins/del in ASD individuals [86] evoking changes in the brain epigenome. The authors concluded that although folate status and/or associated genes might not be the direct cause of ASD, environment (i.e., nutrients)-gene interactions by affecting other gene products might modify ASD risk mainly due to a comprehensive effect of folate machinery on the whole genome [86].

Finally, a recent multicentric study is aiming at determining if reducing folic acid supplementation during late gestation might also reduce maternal UMFA, considered a risk for ASD as well childhood allergy and metabolic diseases [112]. Other studies investigated the potential association between high folate levels in maternal blood and ASD focusing on whether different kinds of folate in cord blood could have specific associations with ASD, reporting that higher UMFA concentrations in cord blood but not 5-methyl-THF or total folate were associated with increased risk of ASD in black children [31,96]. 
Overall, though considering the potential risk associated with specific DHFR and MTHFR haplotypes, and in the light of the recent associations found by the research group in the Genetic-Epigenetic-Mother-Child-Dyad-Study (GEMCDS) that discovered unexpected opposite effects on the onset age of pediatric leukemia according to specific haplotypes carried by the mother or the child [51], further investigations are strongly warranted. Then, before assigning or refusing a definite association, often controversial in the literature, both mother and child dyad genomes must be taken into account [96] to properly readdress a targeted periconceptional use of supplementation.

\subsection{CBS Gene and Functions}

$C B S$ gene is located on chromosome 21 (21q22.3), it comprises a total of 23 exons and codes for a protein product of 551 aa [113]. The gene contains alternative exons 1 (exons la-le) and other exons defined by multiple alternatively spliced transcripts encoding the $C B S$ protein [113]. The $5^{\prime} \mathrm{UTR}$ contains one of five alternatively used exons and one constantly present exon, while $3^{\prime}$ UTR is encoded by exons 16 and 17 [113]. The protein is organized as a homotetramer of $63 \mathrm{kDa}$ subunits and each subunit binds two substrates (i.e., homocysteine and serine) [114] to catalyze the irreversible metabolization of Hcy to cysteine. It requires vitamin B6 as an essential cofactor [115] and by means of the transsulfuration pathway [116,117] irreversibly removes Hcy from the methionine cycle lowering, in turn, Hcy from circulation [117]. Different from Hcy, cysteine can be taken from the diet, if cysteine supply is high, the oxidative/desulfuration pathways may result unbalanced. Briefly, high Hcy causes redox imbalance and oxidative stress with free radical release, while cysteine being an antioxidant strongly contrasts oxidative damage also affecting DNA, lipids, and proteins highlighting a role of the ASD/imprinting/epigenetic/disorders axis [118,119].

Of note, cysteine is fundamental for protein production and for glutathione generation, the potent mediator with antioxidant and detoxifying effects against xenobiotics [115]. Very high circulating Hcy levels are risk factors for different pathological situations and levels above 50-100 $\mathrm{mol} / \mathrm{L}$ are considered an intermediate-severe condition [59]. An intraindividual variability, due to the presence of the main gene variants described above, is often described and individual genetics is globally involved in the final Hcy blood concentration.

Functional defects of the CBS enzyme cause classical homocystinuria, and associations have been demonstrated between altered methionine/homocysteine metabolism and cognitive or behavioral diseases, ASD included [120]. CBS gene defects are associated with reduction of normal vascular functions, increased systemic oxidative stress, brain atrophy, and worsening of the neurological impairment in various central nervous system disorders, in primis autism, epilepsy, Parkinson's disease, Alzheimer's disease, and dementia [101,120,121]. In a study on ASD children aimed at identifying biomarkers of increased oxidative stress and impaired methylation score, lower blood levels of methionine, SAM, Hcy, cystathionine, cysteine, and total glutathione and higher blood levels of $\mathrm{SAH}$, adenosine, and oxidized glutathione have been found potentially associated with behavioral disturbances [120]. Authors observed that anomalies in the metabolic profile, particularly in the transsulfuration pathway, could be responsible for higher susceptibility to environmental and/or to cellular oxidative stress and impaired methylation capability, responsible for the clinical phenotype [120]. As stated above, a decreased CBS activity, controlled by methionine and SAM, will increase the cysteine requirement, leading to a decrease in total glutathione concentrations, suggesting that ASD patients are more susceptible and less protected against oxidative stress, also in an epigenetic perspective [118-120]. Uncontrolled and unbalanced oxidative stress, also exacerbated by increased local tissue iron deposits, is a crucial factor in determining tissue damage and cognitive decline, and as recently found it is strictly directed by genetic interactions of iron homeostasis genes and APOE haplotypes [23,122,123].

More than one-hundred different mutations, prevalently clustered in exon 3, 8, and 10 , have been reported in the $C B S$ gene as causative of complex diseases [101,113]. In a 
study on schizophrenia, it has been reported an association between the common CBS polymorphism of 68-bp insertion (844ins68) with increased disease risk [124]. Other studies demonstrated an association of CBS polymorphisms with ASD children [93] as the C699T variant (rs234706) in which 699TT-homozygotes and CT-heterozygotes were significantly more represented among ASD cases compared to healthy controls with the polymorphism playing also a role in sleep and gastrointestinal disorders [93]. Interestingly, the frequency of the T-allele had a significant association with the high score of the Childhood Autism Rating Scale (CARS) and with other clinical data related to ASD participants [93].

Finally, a recent study on premature infants with encephalopathy occurring in the setting of hypoxia-ischemia, suggested that neonatal brain injury and long-term damage was due to $C B S$ upregulation, highlighting this pathway as a potential molecular target to counteract encephalopathy in premature infants also taking into account that up to $50 \%$ of these children showed ASD [125].

\section{One-Carbon Metabolism in Autism and in Other Neurological Diseases: Brain Sex-Related Insights}

In many complex diseases, neurological conditions included, sex differences are associated with prevalence, course of the disease and outcome [126,127]. Among behavioral abnormalities, epidemiological studies consistently reported higher ASD prevalence in males compared with females (male: female ratio about 4:1), also considering the different role of abnormalities detected in the mother or father of ASD children $[16,126,128,129]$. Moreover, ASD females show a less severe disease phenotype highlighting sex differences also in a genetic view [130].

GWAS are demonstrating that including balanced sexes in the recruitment and analyses and stratifying data by sex strongly improved the comprehension and the ability to transfer experimental data in the clinical practice [131]. In a wide prospective study of newly diagnosed preschool ASD children, it was observed that the sex of the affected child with ASD was the only significant predictor of differential trajectories of symptoms over time [132]. Boys had more stable, severe symptoms over time, whereas girls exhibited less severe symptoms and improvement over time [132] in accordance with the evidence that some girls no longer showed cognitive and language problems at follow-up [132].

An increased sex gap was also present when considering prevalence among very young patients [16]. The male-to-female ratio was 1.16:1.0 when using an at-risk sample of infants ranging from 22 to 39 months [133,134]. Moreover, research also highlighted that the reported ratio was affected by the level of cognitive ability and the greater the attention defects the less the difference between male/female ratios was apparent [133]. Finally, infants aged 70-75 months had an overall male-to-female ratio of 2.61:1.0, and again when testing only those with an IQ below 50 the male-to-female ratio fell to 1.31:1.0 [133,134]. Therefore, it would also be important to examine symptom differences between sexes, also considering the specific developmental level [135].

Furthermore, autistic male and female patients have divergent peculiar symptoms with males displaying heightened aggressiveness and repetitive behavior, while females experiencing greater anxiety and depression [136]. There is also a discrepancy when diagnosing a male child with autism compared to a female child, due to the differences in the symptom picture, which still has in part a male-centered component in the official criteria to diagnose and globally this contributes to a preferentially earlier diagnosis in male children $[137,138]$.

Since there exists a clear difference in autism between sexes, this points out to differences in the biological pathways underlying ASD development in the two sexes $[134,136]$. From a molecular perspective, defects in folate metabolism can be targeted to achieve a sex specific prevention program, as well as treatment and therapy [12]. As a paradigm of this approach, in a different clinical context it has been shown that MTHFR C677T polymorphism had different methylation effects stratified by sex in patients with schizophrenia with female patients showing a tendency towards lower rates of global methylation [139]. The combination of sex and other variables correlated with global methylation revealed that 
sex and MTHFR genotype strongly interacted, ascribing to 677 TT-homozygous females the lowest overall methylation rates compared to males [139].

Interestingly, preclinical sex-oriented researches demonstrated correlations between MTFHR polymorphic status and observed behaviors in mice [140]. In particular, newborn mice with MTHFR 677TT genotype when exposed to antiepileptic drugs were positively associated with higher altered social behaviors differently expressed among female and male mice [140]. This behavioral outcome was correlated with different cortical potency of reeling level, and with altered proportions of key proteins involved in the excitation/inhibition synapses in the brain of female mice [140].

Information and experimental data on sex differences between human brain developments according to the brain epigenome are very limited. Since some of such differences are evident in the brain before birth, they should happen during pregnancy in which sex imprinting actions can be mainly ascribed to the mother and less to the developing fetus. After birth, the genome, epigenome, and gender of the newborn take place, mutually interacting in determining the ultimate brain epigenome (Figure 2).

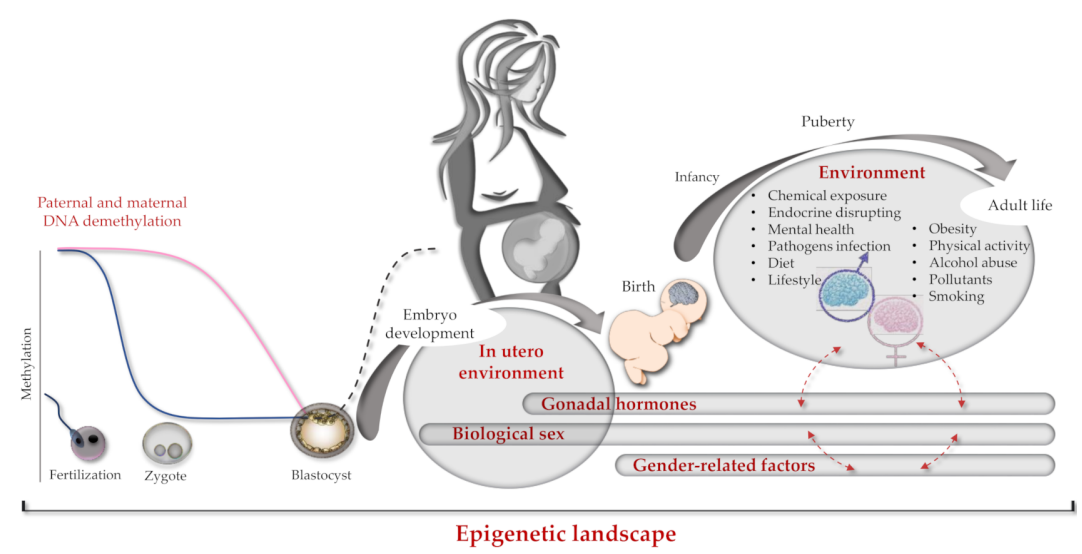

Figure 2. Brain epigenome imprinting. Schematic representation of genetics and epigenetics interactions occurring from conception to individual adult life. On the left, paternal and maternal hemigenome DNA demethylation processes occurring during fertilization (blue and pink lines respectively). In the middle, de novo global genome methylation at the blastocyst phase is shown as a dark dashed line. On the right, dashed red arrows indicate cross-interactions between different epigenetics factors (e.g., sex and gender).

\section{The Role of Epigenetics and Genetics: The Paradigm of the Folate Cycle}

Epigenetics may provide a different view to the mechanisms and insights of the pathophysiological processes in complex diseases such as developmental diseases, potentially leading to the identification of innovative therapeutic targets and strategies [141]. In a few words, epigenetics can be resumed as modifications of heritable phenotype variations with no alterations of the DNA sequence, and epigenome dysregulations have been recognized as hallmarks in several diseases. In mammalians, epigenetic modifications influence transgenerational inheritance by DNA methylation and histone modifications (i.e., methylation, acetylation, phosphorylation, sumoylation, and histone gene variants) together with small and long non-coding RNAs (i.e., micro-RNA) [19,142]. Epigenetics emerges as a dynamic and reversible process occurring in multiple rounds with a key role of modifications during the first phases of embryonic development when parental genetic/epigenetic marks can be inherited by the offspring as recently reviewed [142]. Strong sex differences already start at the zygote stage by the completely different methylation process occurring within the mother and father hemigenomes: at an early zygote status for the paternal hemigenome, characterized by an active enzymatic dependent methylation erasure before DNA replication, and by a slower rate of spontaneous methylation erasure for the maternal hemigenome during the following cell divisions (Figure 2). This complex process is measurable by assessing the relative ratio of 5-methyl-cytosine and 
5-hydroxy-methyl-cytosine $(5 \mathrm{mC} / 5 \mathrm{hmC})$ the latter being the first oxidative product in the active demethylation of $5 \mathrm{mC}[143,144]$.

Basically, in the brain, a de novo DNA methylation driven by DNA methyltransferases (DNMTs) is necessary for learning and memory activities and the methylation degree is linked to specific neural activity [145]. Interestingly, brain DNA contains $5 \mathrm{hmC}$ and whole genome bisulfite sequencing (WGBS) has shown elevated percentages of non-CpG methylated residues revealing that the most common base substitution is an adenine (i.e., $\mathrm{mCA}$ ). Global methylome reorganization occurs during fetal/early-childhood development, and during this period highly conserved non-CpG methylation (i.e., $\mathrm{mCH}$ ) becomes the prevalent form of methylation in the human brain genome [146]. This modification prevails during postnatal development of the brain concomitantly with synaptogenesis and circumstantial personal experiences altogether strongly contributing to define cell identity with possible alterations during perinatal estradiol exposition.

Since epigenetic modifications control how and to what extent genes must be expressed, and respond to the environment stimuli, any disturbance of the normal interplay between environmental factors and epigenetic reprogramming may result in the occurrence of specific disease conditions. This mechanism has been suggested for autism initiation/progression including the onset-age. In a recent study, 84 rare epigenetic variations (epivariations) have been identified in autism compared to healthy controls [147], with a trend of epivariations to cluster in affected autistic patients compared to unaffected brothers/sisters within the autism families [147]. Many genetic and epigenetic factors potentially involved in ASD, as well as the crosstalk between major gut microbiota metabolites in autistic children and epigenetic changes, have also been recently discussed and reviewed [148,149]. Interestingly, by investigating the different aberrant DNA methylation degrees, an important sex-related difference between autistic children and sex-matched non-autistic siblings has been found [150]. In particular, the authors reported that some sex-specific methylation patterns (linked to mitochondrial dysfunction and metabolic disorders) may provide a degree of protection against autism in females, highlighting sex-specific epigenetic traits that require dedicated investigations [150]. Of note, sex-based epigenetic differences (i.e., methylation rate) on key genes, such as the oxytocin receptor gene OXTR, have also been recently reported [151]. However, the mechanisms underlying these epigenetic changes are still unclear and strongly heterogeneous. The suggested critical processes are related to changes in levels of transcription of key genes during specific crucial phases of central nervous system development, also affected by genetic and/or environmental dynamics.

Since it has been demonstrated that several environmental factors including progenitor's diet and lifestyle can influence the inherited epigenetics trait [142,152,153], the folate and folate cycle may represent a paradigmatic example of the inception of epigenetics in response to environmental variances. As mentioned above, crucial epigenetic reprogramming occurs during the first stages of embryo development, starting from the fertilization step with potential effects till the stage of morula/blastocyst when the reconstituted diploid genome begins the remethylation program [154]. Accordingly, maternal/paternal folate status due to both genetically inherited predispositions and/or folate intake might differentially affect the global embryonic DNA methylation program [51,155]. Of note, in a preclinical model of autism it has been recently demonstrated that epigenetic dysregulation (i.e., hypomethylation) of key genes (brain-derived neurotrophic factor gene BDNF and glial fibrillary acidic protein GFAP gene) involved in the induced autistic-like behaviors in a neonatal isolation model, can be reversed by folic acid administration [156]. Interestingly, the treatment effects were mediated by the epigenetic regulation of BDNF and GFAP by restoring the hypomethylated status of the two gene promoters and by antioxidant effects, opening stimulating translational applications.

Histone methylation processes by histone methyltransferases (HMTs) are a crucial part of the maternal influence effects on offspring. This may result via the epigenetic code regulation of chromatin status (including chromatic reorganization), affecting in turn 
gene expression [152]. HMT activities depend on intracellular SAM levels and HMT gene variants, connecting mother-child metabolism and cell nutrient availability $[19,157]$. Folate deficiency and one-carbon metabolism genes also result in altered epigenetic histone modifications and during pregnancy, they have been correlated with increased risk of neurocognitive and/or neurobehavioral deficits such as ASD and attention deficit hyperactivity disorders [158]. Finally, modified histones are secreted in the uterine environment and may influence embryo brain development by transgenerational epigenetic histone modifications [159].

\section{Conclusions and Future Perspectives in ASD}

Although the key role of folate isoforms balance/dysregulation in some complex pathological conditions has been demonstrated, more efforts and dedicated studies are needed to conclusively identify the most critical factors involved in ASD establishment. In particular, there is the mandatory need to elucidate the precise mechanisms by which sex-specific factors can modulate disease onset, severity and the different disease phenotypes at presentation, as well as how they can help and guide the choice of useful or unsafe dedicated treatments. To face these challenges, the synergy between advanced technologies and experimental/clinical investigations including pharmacogenetics/genomics/OMICS approaches [160-163] and personalized medicine [164] will allow a progression in the pathophysiological understanding of complex neurodevelopmental/neurological diseases. Earlier identification of informative molecular and biological biomarkers and an appropriate therapeutic strategy definition are the unique effective strategy to follow (Figure 3). Accordingly, the sex gap in ASD prevalence reported to be about 4:1 (males-to-females respectively) appears to be more realistically close to 3:1 due to a potential diagnostic gender bias that does not efficiently include ASD girls, that are therefore at high risk of not receiving a proper and early diagnosis [165].

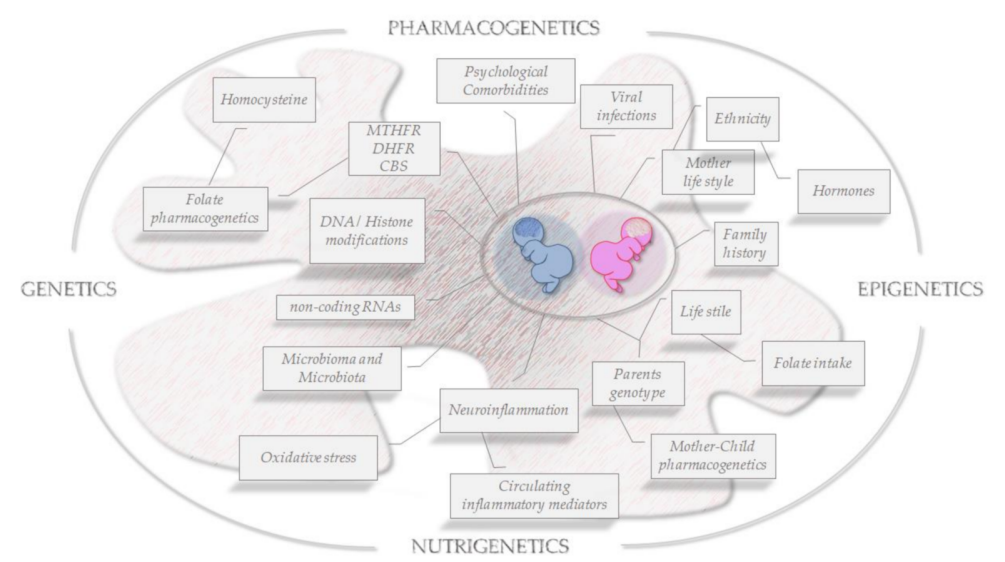

Figure 3. Folate OMICS-environment interactions on brain epigenomics. Snapshot of key risk factors for ASD development and key transgenerational pathophysiological features to be faced in a sex/gender approach.

In conclusion, due to an unavoidable mutual influence between the psychologi$\mathrm{cal} /$ social gender and the biological sex in human life, and that they both interact on the brain development by genetics and epigenetics actions, we cannot easily separate the effect of sex or gender on the brain epigenome establishment. Then we must begin to consider sex and gender combined together any time a difference appears in the clinical phenotype between women and men [166].

Author Contributions: Conceptualization, D.G.; Writing-original draft preparation and visualization, D.G., J.A.S. and V.T.; Writing—review and editing, D.G., J.A.S., V.T., G.L., I.G., D.M. and A.V.S. All authors have read and agreed to the published version of the manuscript.

Funding: Local grant from University of Ferrara FAR and FIR (to D.G. and V.T.) 
Institutional Review Board Statement: Not applicable.

Informed Consent Statement: Not applicable.

Data Availability Statement: Data is contained within the article.

Acknowledgments: The authors would like to thank Fondazione Carlo Fornasini (Poggio Renatico, Ferrara, Italy).

Conflicts of Interest: The authors declare no conflict of interest.

\section{References}

1. Kanner, L. Autistic disturbances of affective contact. Acta Paedopsychiatr. 1968, 35, 100-136. [PubMed]

2. Bhat, S.; Acharya, U.R.; Adeli, H.; Bairy, G.M.; Adeli, A. Autism: Cause factors, early diagnosis and therapies. Rev. Neurosci. 2014, 25, 841-850. [CrossRef] [PubMed]

3. Constantino, J.N.; Todd, R.D. Autistic traits in the general population: A twin study. Arch. Gen. Psychiatry 2003, 60, 524-530. [CrossRef] [PubMed]

4. Available online: https://www.nimh.nih.gov/health/topics/autism-spectrum-disorders-asd/index.shtml (accessed on 8 March 2021).

5. Chaste, P.; Leboyer, M. Autism risk factors: Genes, environment, and gene-environment interactions. Dialogues Clin. Neurosci. 2012, 14, 281-292.

6. Rossignol, D.A.; Frye, R.E. A review of research trends in physiological abnormalities in autism spectrum disorders: Immune dysregulation, inflammation, oxidative stress, mitochondrial dysfunction and environmental toxicant exposures. Mol. Psychiatry 2012, 17, 389-401. [CrossRef]

7. Tisato, V.; Gonelli, A.; Voltan, R.; Secchiero, P.; Zauli, G. Clinical perspectives of TRAIL: Insights into central nervous system disorders. Cell Mol. Life Sci. 2016, 73, 2017-2027. [CrossRef]

8. Zheng, Y.; Verhoeff, T.A.; Perez Pardo, P.; Garssen, J.; Kraneveld, A.D. The Gut-Brain Axis in Autism Spectrum Disorder: A Focus on the Metalloproteases ADAM10 and ADAM17. Int. J. Mol. Sci. 2020, 22, 118. [CrossRef]

9. Baranova, J.; Dragunas, G.; Botellho, M.C.S.; Ayub, A.L.P.; Bueno-Alves, R.; Alencar, R.R.; Papaiz, D.D.; Sogayar, M.C.; Ulrich, H.; Correa, R.G. Autism Spectrum Disorder: Signaling Pathways and Prospective Therapeutic Targets. Cell Mol. Neurobiol. 2020. [CrossRef]

10. Melamed, I.R.; Heffron, M.; Testori, A.; Lipe, K. A pilot study of high-dose intravenous immunoglobulin 5\% for autism: Impact on autism spectrum and markers of neuroinflammation. Autism Res. 2018, 11, 421-433. [CrossRef]

11. Sandin, S.; Lichtenstein, P.; Kuja-Halkola, R.; Hultman, C.; Larsson, H.; Reichenberg, A. The Heritability of Autism Spectrum Disorder. JAMA 2017, 318, 1182-1184. [CrossRef]

12. Guerra, D.J. The molecular genetics of autism spectrum disorders: Genomic mechanisms, neuroimmunopathology, and clinical implications. Autism Res. Treat. 2011, 2011, 398636. [CrossRef]

13. Razak, K.A.; Dominick, K.C.; Erickson, C.A. Developmental studies in fragile X syndrome. J. Neurodev. Disord. 2020, 12, 13. [CrossRef]

14. Zafeiriou, D.I.; Ververi, A.; Dafoulis, V.; Kalyva, E.; Vargiami, E. Autism spectrum disorders: The quest for genetic syndromes. Am. J. Med. Genet. B Neuropsychiatr. Genet. 2013, 162B, 327-366. [CrossRef]

15. Rodier, P.M.; Ingram, J.L.; Tisdale, B.; Nelson, S.; Romano, J. Embryological origin for autism: Developmental anomalies of the cranial nerve motor nuclei. J. Comp. Neurol. 1996, 370, 247-261. [CrossRef]

16. Werling, D.M.; Geschwind, D.H. Sex differences in autism spectrum disorders. Curr. Opin. Neurol. 2013, 26, 146-153. [CrossRef]

17. Barrionuevo, F.; Scherer, G. SOX E genes: SOX9 and SOX8 in mammalian testis development. Int. J. Biochem. Cell Biol. 2010, 42, 433-436. [CrossRef]

18. Demontis, D.; Walters, R.K.; Martin, J.; Mattheisen, M.; Als, T.D.; Agerbo, E.; Baldursson, G.; Belliveau, R.; Bybjerg-Grauholm, J.; Baekvad-Hansen, M.; et al. Discovery of the first genome-wide significant risk loci for attention deficit/hyperactivity disorder. Nat. Genet. 2019, 51, 63-75. [CrossRef]

19. Satterstrom, F.K.; Kosmicki, J.A.; Wang, J.; Breen, M.S.; De Rubeis, S.; An, J.Y.; Peng, M.; Collins, R.; Grove, J.; Klei, L.; et al. Large-Scale Exome Sequencing Study Implicates Both Developmental and Functional Changes in the Neurobiology of Autism. Cell 2020, 180, 568-584.e523. [CrossRef]

20. Grove, J.; Ripke, S.; Als, T.D.; Mattheisen, M.; Walters, R.K.; Won, H.; Pallesen, J.; Agerbo, E.; Andreassen, O.A.; Anney, R.; et al. Identification of common genetic risk variants for autism spectrum disorder. Nat. Genet. 2019, 51, 431-444. [CrossRef]

21. Pivina, L.; Semenova, Y.; Dosa, M.D.; Dauletyarova, M.; Bjorklund, G. Iron Deficiency, Cognitive Functions, and Neurobehavioral Disorders in Children. J. Mol. Neurosci. 2019, 68, 1-10. [CrossRef]

22. Genovese, A.; Butler, M.G. Clinical Assessment, Genetics, and Treatment Approaches in Autism Spectrum Disorder (ASD). Int. J. Mol. Sci. 2020, 21, 4726. [CrossRef] [PubMed]

23. Tisato, V.; Zuliani, G.; Vigliano, M.; Longo, G.; Franchini, E.; Secchiero, P.; Zauli, G.; Paraboschi, E.M.; Vikram Singh, A.; Serino, M.L.; et al. Gene-gene interactions among coding genes of iron-homeostasis proteins and APOE-alleles in cognitive impairment diseases. PLoS ONE 2018, 13, e0193867. [CrossRef] [PubMed] 
24. Gemmati, D.; Varani, K.; Bramanti, B.; Piva, R.; Bonaccorsi, G.; Trentini, A.; Manfrinato, M.C.; Tisato, V.; Care, A.; Bellini, T. "Bridging the Gap" Everything that Could Have Been Avoided If We Had Applied Gender Medicine, Pharmacogenetics and Personalized Medicine in the Gender-Omics and Sex-Omics Era. Int. J. Mol. Sci. 2019, 21, 296. [CrossRef] [PubMed]

25. Tornese, G.; Iafusco, D.; Monasta, L.; Agnoletto, C.; Tisato, V.; Ventura, A.; Zauli, G.; Secchiero, P. The levels of circulating TRAIL at the onset of type 1 diabetes are markedly decreased in patients with ketoacidosis and with the highest insulin requirement. Acta Diabetol. 2014, 51, 239-246. [CrossRef]

26. Agostinis, C.; Bulla, R.; Tisato, V.; De Seta, F.; Alberico, S.; Secchiero, P.; Zauli, G. Soluble TRAIL is elevated in recurrent miscarriage and inhibits the in vitro adhesion and migration of HTR8 trophoblastic cells. Hum. Reprod. 2012, 27, $2941-2947$. [CrossRef]

27. Gemmati, D.; Occhionorelli, S.; Tisato, V.; Vigliano, M.; Longo, G.; Gonelli, A.; Sibilla, M.G.; Serino, M.L.; Zamboni, P. Inherited genetic predispositions in F13A1 and F13B genes predict abdominal adhesion formation: Identification of gender prognostic indicators. Sci. Rep. 2018, 8, 16916. [CrossRef]

28. Myers, S.M.; Voigt, R.G.; Colligan, R.C.; Weaver, A.L.; Storlie, C.B.; Stoeckel, R.E.; Port, J.D.; Katusic, S.K. Autism Spectrum Disorder: Incidence and Time Trends Over Two Decades in a Population-Based Birth Cohort. J. Autism Dev. Disord. 2019, 49, 1455-1474. [CrossRef]

29. Eshraghi, A.A.; Liu, G.; Kay, S.S.; Eshraghi, R.S.; Mittal, J.; Moshiree, B.; Mittal, R. Epigenetics and Autism Spectrum Disorder: Is There a Correlation? Front. Cell Neurosci. 2018, 12, 78. [CrossRef]

30. Sedley, L. Advances in Nutritional Epigenetics-A Fresh Perspective for an Old Idea. Lessons Learned, Limitations, and Future Directions. Epigenet. Insights 2020, 13, 2516865720981924. [CrossRef]

31. Raghavan, R.; Riley, A.W.; Volk, H.; Caruso, D.; Hironaka, L.; Sices, L.; Hong, X.; Wang, G.; Ji, Y.; Brucato, M.; et al. Maternal Multivitamin Intake, Plasma Folate and Vitamin B12 Levels and Autism Spectrum Disorder Risk in Offspring. Paediatr. Perinat. Epidemiol. 2018, 32, 100-111. [CrossRef]

32. Naderi, N.; House, J.D. Recent Developments in Folate Nutrition. Adv. Food Nutr. Res. 2018, 83, 195-213. [CrossRef] [PubMed]

33. Bordeleau, M.; Fernandez de Cossio, L.; Chakravarty, M.M.; Tremblay, M.E. From Maternal Diet to Neurodevelopmental Disorders: A Story of Neuroinflammation. Front. Cell Neurosci. 2020, 14, 612705. [CrossRef]

34. Shaik Mohammad, N.; Sai Shruti, P.; Bharathi, V.; Krishna Prasad, C.; Hussain, T.; Alrokayan, S.A.; Naik, U.; Radha Rama Devi, A. Clinical utility of folate pathway genetic polymorphisms in the diagnosis of autism spectrum disorders. Psychiatr. Genet. 2016, 26, 281-286. [CrossRef]

35. Long, S.; Goldblatt, J. MTHFR genetic testing: Controversy and clinical implications. Aust. Fam. Physician 2016, 45, 237-240.

36. James, S.J. Autism and Folate-dependent One-carbon Metabolism: Serendipity and Critical Branch-point Decisions in Science. Glob. Adv. Health Med. 2013, 2, 48-51. [CrossRef]

37. Lintas, C. Linking genetics to epigenetics: The role of folate and folate-related pathways in neurodevelopmental disorders. Clin. Genet. 2019, 95, 241-252. [CrossRef]

38. Xu, J.; Sinclair, K.D. One-carbon metabolism and epigenetic regulation of embryo development. Reprod. Fertil. Dev. 2015, 27, 667-676. [CrossRef]

39. Tamura, T.; Picciano, M.F. Folate and human reproduction. Am. J. Clin. Nutr. 2006, 83, 993-1016. [CrossRef]

40. Desai, A.; Sequeira, J.M.; Quadros, E.V. The metabolic basis for developmental disorders due to defective folate transport. Biochimie 2016, 126, 31-42. [CrossRef]

41. Lucock, M. Folic acid: Nutritional biochemistry, molecular biology, and role in disease processes. Mol. Genet. Metab. 2000, 71, 121-138. [CrossRef]

42. Lan, X.; Field, M.S.; Stover, P.J. Cell cycle regulation of folate-mediated one-carbon metabolism. Wiley Interdiscip. Rev. Syst. Biol. Med. 2018, 10, e1426. [CrossRef] [PubMed]

43. Gemmati, D. Folate-Pathway Gene Variants in Cancer: Haematological Malignancies; Gemmati, D., Ed.; Transworld Research Network: Trivandrum, India, 2008; p. 269.

44. Field, M.S.; Kamynina, E.; Chon, J.; Stover, P.J. Nuclear Folate Metabolism. Annu. Rev. Nutr. 2018, 38, 219-243. [CrossRef] [PubMed]

45. Crider, K.S.; Yang, T.P.; Berry, R.J.; Bailey, L.B. Folate and DNA methylation: A review of molecular mechanisms and the evidence for folate's role. Adv. Nutr. 2012, 3, 21-38. [CrossRef] [PubMed]

46. Cai, S.; Quan, S.; Yang, G.; Ye, Q.; Chen, M.; Yu, H.; Wang, G.; Wang, Y.; Zeng, X.; Qiao, S. One Carbon Metabolism and Mammalian Pregnancy Outcomes. Mol. Nutr. Food Res. 2020, e2000734. [CrossRef]

47. Gemmati, D.; De Mattei, M.; Catozzi, L.; Della Porta, M.; Serino, M.L.; Ambrosio, C.; Cuneo, A.; Friso, S.; Krampera, M.; Orioli, E.; et al. DHFR 19-bp insertion/deletion polymorphism and MTHFR C677T in adult acute lymphoblastic leukaemia: Is the risk reduction due to intracellular folate unbalancing? Am. J. Hematol. 2009, 84, 526-529. [CrossRef]

48. Gemmati, D.; Ongaro, A.; Scapoli, G.L.; Della Porta, M.; Tognazzo, S.; Serino, M.L.; Di Bona, E.; Rodeghiero, F.; Gilli, G.; Reverberi, R.; et al. Common gene polymorphisms in the metabolic folate and methylation pathway and the risk of acute lymphoblastic leukemia and non-Hodgkin's lymphoma in adults. Cancer Epidemiol. Biomark. Prev. 2004, 13, 787-794.

49. Gemmati, D.; Previati, M.; Serino, M.L.; Moratelli, S.; Guerra, S.; Capitani, S.; Forini, E.; Ballerini, G.; Scapoli, G.L. Low folate levels and thermolabile methylenetetrahydrofolate reductase as primary determinant of mild hyperhomocystinemia in normal and thromboembolic subjects. Arterioscler. Thromb. Vasc. Biol. 1999, 19, 1761-1767. [CrossRef] 
50. Ongaro, A.; De Mattei, M.; Della Porta, M.G.; Rigolin, G.; Ambrosio, C.; Di Raimondo, F.; Pellati, A.; Masieri, F.F.; Caruso, A.; Catozzi, L.; et al. Gene polymorphisms in folate metabolizing enzymes in adult acute lymphoblastic leukemia: Effects on methotrexate-related toxicity and survival. Haematologica 2009, 94, 1391-1398. [CrossRef]

51. Tisato, V.; Muggeo, P.; Lupiano, T.; Longo, G.; Serino, M.L.; Grassi, M.; Arcamone, E.; Secchiero, P.; Zauli, G.; Santoro, N.; et al. Maternal Haplotypes in DHFR Promoter and MTHFR Gene in Tuning Childhood Acute Lymphoblastic Leukemia Onset-Latency: Genetic/Epigenetic Mother/Child Dyad Study (GEMCDS). Genes 2019, 10, 634. [CrossRef]

52. Jhee, K.H.; Kruger, W.D. The role of cystathionine $\beta$-synthase in homocysteine metabolism. Antioxid. Redox Signal. 2005, 7, 813-822. [CrossRef]

53. Bhargava, S.; Ali, A.; Bhargava, E.K.; Manocha, A.; Kankra, M.; Das, S.; Mohan Srivastava, L. Lowering homocysteine and modifying nutritional status with folic acid and vitamin B(12) in Indian patients of vascular disease. J. Clin. Biochem. Nutr. 2012, 50, 222-226. [CrossRef]

54. Cohen, E.; Margalit, I.; Shochat, T.; Goldberg, E.; Krause, I. Sex Differences in Folate Levels: A Cross Sectional Study of a Large Cohort from Israel. Isr. Med. Assoc. J. 2021, 23, 17-22.

55. Russo, G.T.; Friso, S.; Jacques, P.F.; Rogers, G.; Cucinotta, D.; Wilson, P.W.; Ordovas, J.M.; Rosenberg, I.H.; Selhub, J.; Framingham Offspring Study, C. Age and gender affect the relation between methylenetetrahydrofolate reductase C677T genotype and fasting plasma homocysteine concentrations in the Framingham Offspring Study Cohort. J. Nutr. 2003, 133, 3416-3421. [CrossRef]

56. Miles, E.W.; Kraus, J.P. Cystathionine $\beta$-synthase: Structure, function, regulation, and location of homocystinuria-causing mutations. J. Biol. Chem. 2004, 279, 29871-29874. [CrossRef]

57. Gatarek, P.; Rosiak, A.; Borowczyk, K.; Glowacki, R.; Kaluzna-Czaplinska, J. Higher Levels of Low Molecular Weight Sulfur Compounds and Homocysteine Thiolactone in the Urine of Autistic Children. Molecules 2020, 25, 973. [CrossRef]

58. Fuentes-Albero, M.; Cauli, O. Homocysteine Levels in Autism Spectrum Disorder: A Clinical Update. Endocr. Metab. Immune Disord. Drug Targets 2018, 18, 289-296. [CrossRef]

59. Azzini, E.; Ruggeri, S.; Polito, A. Homocysteine: Its Possible Emerging Role in At-Risk Population Groups. Int. J. Mol. Sci. 2020, 21, 1421. [CrossRef]

60. Fulceri, F.; Morelli, M.; Santocchi, E.; Cena, H.; Del Bianco, T.; Narzisi, A.; Calderoni, S.; Muratori, F. Gastrointestinal symptoms and behavioral problems in preschoolers with Autism Spectrum Disorder. Dig. Liver Dis. 2016, 48, 248-254. [CrossRef]

61. Sun, C.; Zou, M.; Zhao, D.; Xia, W.; Wu, L. Efficacy of Folic Acid Supplementation in Autistic Children Participating in Structured Teaching: An Open-Label Trial. Nutrients 2016, 8, 337. [CrossRef]

62. Jozefczuk, J.; Kasprzycka, W.; Czarnecki, R.; Graczyk, A.; Jozefczuk, P.; Magda, K.; Lampart, U. Homocysteine as a Diagnostic and Etiopathogenic Factor in Children with Autism Spectrum Disorder. J. Med. Food 2017, 20, 744-749. [CrossRef]

63. Frye, R.E.; Slattery, J.C.; Quadros, E.V. Folate metabolism abnormalities in autism: Potential biomarkers. Biomark. Med. 2017, 11, 687-699. [CrossRef] [PubMed]

64. Schaevitz, L.R.; Berger-Sweeney, J.E. Gene-environment interactions and epigenetic pathways in autism: The importance of one-carbon metabolism. ILAR J. 2012, 53, 322-340. [CrossRef] [PubMed]

65. Wisniowiecka-Kowalnik, B.; Nowakowska, B.A. Genetics and epigenetics of autism spectrum disorder-current evidence in the field. J. Appl. Genet. 2019, 60, 37-47. [CrossRef] [PubMed]

66. Liew, S.C.; Gupta, E.D. Methylenetetrahydrofolate reductase (MTHFR) C677T polymorphism: Epidemiology, metabolism and the associated diseases. Eur. J. Med. Genet. 2015, 58, 1-10. [CrossRef] [PubMed]

67. Liu, J.H.; Zhu, C.; Zheng, K.; Tang, W.; Gao, L.L.; Trihn, T.H.; Emily Wu, H.; Chen, D.C.; Hong Xiu, M.; Yang Zhang, X. MTHFR Ala222Val polymorphism and clinical characteristics confer susceptibility to suicide attempt in chronic patients with schizophrenia. Sci. Rep. 2020, 10, 5008. [CrossRef] [PubMed]

68. Scaglione, F.; Panzavolta, G. Folate, folic acid and 5-methyltetrahydrofolate are not the same thing. Xenobiotica 2014, 44, 480-488. [CrossRef] [PubMed]

69. Fan, S.; Yang, B.; Zhi, X.; Wang, Y.; Zheng, Q.; Sun, G. Combined genotype and haplotype distributions of MTHFR C677T and A1298C polymorphisms: A cross-sectional descriptive study of 13,473 Chinese adult women. Medicine (Baltim.) 2016, 95 , e5355. [CrossRef]

70. DeVilbiss, E.A.; Gardner, R.M.; Newschaffer, C.J.; Lee, B.K. Maternal folate status as a risk factor for autism spectrum disorders: A review of existing evidence. Br. J. Nutr. 2015, 114, 663-672. [CrossRef]

71. Pu, D.; Shen, Y.; Wu, J. Association between MTHFR gene polymorphisms and the risk of autism spectrum disorders: A meta-analysis. Autism Res. 2013, 6, 384-392. [CrossRef]

72. Mohammad, N.S.; Jain, J.M.; Chintakindi, K.P.; Singh, R.P.; Naik, U.; Akella, R.R. Aberrations in folate metabolic pathway and altered susceptibility to autism. Psychiatr. Genet. 2009, 19, 171-176. [CrossRef]

73. Cunha, A.L.; Hirata, M.H.; Kim, C.A.; Guerra-Shinohara, E.M.; Nonoyama, K.; Hirata, R.D. Metabolic effects of C677T and A1298C mutations at the MTHFR gene in Brazilian children with neural tube defects. Clin. Chim. Acta 2002, 318, 139-143. [CrossRef]

74. Xin, Y.; Wu, L.; Lu, X.; Shangguan, S.; Wang, Z.; Chang, S.; Yin, J.; Piao, W.; Zhang, T.; Wang, L. Effects of MTHFR A1298C polymorphism on peripheral blood folate concentration in healthy populations: A meta-analysis of observational studies. Asia Pac. J. Clin. Nutr. 2018, 27, 718-727. [CrossRef] 
75. Stevens, A.J.; Rucklidge, J.J.; Kennedy, M.A. Epigenetics, nutrition and mental health. Is there a relationship? Nutr. Neurosci. 2018, 21, 602-613. [CrossRef]

76. Isotalo, P.A.; Donnelly, J.G. Prevalence of methylenetetrahydrofolate reductase mutations in patients with venous thrombosis. Mol. Diagn. 2000, 5, 59-66. [CrossRef]

77. Ogino, S.; Wilson, R.B. Genotype and haplotype distributions of MTHFR677C >T and 1298A $>$ C single nucleotide polymorphisms: A meta-analysis. J. Hum. Genet. 2003, 48, 1-7. [CrossRef]

78. Lewis, S.J.; Zammit, S.; Gunnell, D.; Smith, G.D. A meta-analysis of the MTHFR C677T polymorphism and schizophrenia risk. Am. J. Med. Genet. B Neuropsychiatr. Genet. 2005, 135B, 2-4. [CrossRef]

79. Wan, L.; Li, Y.; Zhang, Z.; Sun, Z.; He, Y.; Li, R. Methylenetetrahydrofolate reductase and psychiatric diseases. Transl. Psychiatry 2018, 8, 242. [CrossRef]

80. Orenbuch, A.; Fortis, K.; Taesuwan, S.; Yaffe, R.; Caudill, M.A.; Golan, H.M. Prenatal Nutritional Intervention Reduces AutisticLike Behavior Rates Among Mthfr-Deficient Mice. Front. Neurosci. 2019, 13, 383. [CrossRef]

81. Schmidt, R.J.; Hansen, R.L.; Hartiala, J.; Allayee, H.; Schmidt, L.C.; Tancredi, D.J.; Tassone, F.; Hertz-Picciotto, I. Prenatal vitamins, one-carbon metabolism gene variants, and risk for autism. Epidemiology 2011, 22, 476-485. [CrossRef]

82. Zhang, Z.; Yu, L.; Li, S.; Liu, J. Association Study of Polymorphisms in Genes Relevant to Vitamin B12 and Folate Metabolism with Childhood Autism Spectrum Disorder in a Han Chinese Population. Med. Sci. Monit. 2018, 24, 370-376. [CrossRef]

83. Fadila; Suman, P.; Kumar, P.; Omair, F. Clinical Relevance of Methylenetetrahydrofolate Reductase Genetic Testing in Autism: A Case Report of Successful Clinical Outcome. Cureus 2021, 13, e12586. [CrossRef]

84. Boris, M.; Goldblatt, P.A.; Galanko, J.; James, S.J. Association of MTHFR Gene Variants with Autism. J. Am. Physicians Surg. 2004, 9,3 .

85. James, S.J.; Melnyk, S.; Jernigan, S.; Cleves, M.A.; Halsted, C.H.; Wong, D.H.; Cutler, P.; Bock, K.; Boris, M.; Bradstreet, J.J.; et al. Metabolic endophenotype and related genotypes are associated with oxidative stress in children with autism. Am. J. Med. Genet. B Neuropsychiatr. Genet. 2006, 141B, 947-956. [CrossRef] [PubMed]

86. Adams, M.; Lucock, M.; Stuart, J.; Fardell, S.; Baker, K.; Ng, X. Preliminary evidence for involvement of the folate gene polymorphism 19bp deletion-DHFR in occurrence of autism. Neurosci. Lett. 2007, 422, 24-29. [CrossRef] [PubMed]

87. Liu, X.; Solehdin, F.; Cohen, I.L.; Gonzalez, M.G.; Jenkins, E.C.; Lewis, M.E.; Holden, J.J. Population- and family-based studies associate the MTHFR gene with idiopathic autism in simplex families. J. Autism Dev. Disord. 2011, 41, 938-944. [CrossRef]

88. Schmidt, R.J.; Tancredi, D.J.; Ozonoff, S.; Hansen, R.L.; Hartiala, J.; Allayee, H.; Schmidt, L.C.; Tassone, F.; Hertz-Picciotto, I. Maternal periconceptional folic acid intake and risk of autism spectrum disorders and developmental delay in the CHARGE (CHildhood Autism Risks from Genetics and Environment) case-control study. Am. J. Clin. Nutr. 2012, 96, 80-89. [CrossRef]

89. Guo, T.; Chen, H.; Liu, B.; Ji, W.; Yang, C. Methylenetetrahydrofolate reductase polymorphisms C677T and risk of autism in the Chinese Han population. Genet. Test. Mol. Biomark. 2012, 16, 968-973. [CrossRef] [PubMed]

90. Park, J.; Ro, M.; Pyun, J.A.; Nam, M.; Bang, H.J.; Yang, J.W.; Choi, K.S.; Kim, S.K.; Chung, J.H.; Kwack, K. MTHFR 1298A>C is a risk factor for autism spectrum disorder in the Korean population. Psychiatry Res. 2014, 215, 258-259. [CrossRef] [PubMed]

91. Rai, V. Association of methylenetetrahydrofolate reductase (MTHFR) gene C677T polymorphism with autism: Evidence of genetic susceptibility. Metab. Brain Dis. 2016, 31, 727-735. [CrossRef]

92. El-Baz, F.; El-Aal, M.A.; Kamal, T.M.; Sadek, A.A.; Othman, A.A. Study of the C677T and 1298AC polymorphic genotypes of MTHFR Gene in autism spectrum disorder. Electron. Physician 2017, 9, 5287-5293. [CrossRef]

93. El Shafae, M.; Sabry, J.H.; Behiry, E.G.; Elshahat, S.A.; Zaki, M.S.; Esmaiel, N.N. Association of cystathionine $\beta$ synthase gene polymorphism with cognitive disorders in autistic children. J. Innov. Pharm. Biol. Sci. JIPBS 2017, 4, 5.

94. Sadeghiyeh, T.; Dastgheib, S.A.; Mirzaee-Khoramabadi, K.; Morovati-Sharifabad, M.; Akbarian-Bafghi, M.J.; Poursharif, Z.; Mirjalili, S.R.; Neamatzadeh, H. Association of MTHFR 677C $>$ T and 1298A $>$ C polymorphisms with susceptibility to autism: A systematic review and meta-analysis. Asian J. Psychiatr. 2019, 46, 54-61. [CrossRef] [PubMed]

95. Li, Y.; Qiu, S.; Shi, J.; Guo, Y.; Li, Z.; Cheng, Y.; Liu, Y. Association between MTHFR C677T/A1298C and susceptibility to autism spectrum disorders: A meta-analysis. BMC Pediatr. 2020, 20, 449. [CrossRef] [PubMed]

96. Raghavan, R.; Selhub, J.; Paul, L.; Ji, Y.; Wang, G.; Hong, X.; Zuckerman, B.; Fallin, M.D.; Wang, X. A prospective birth cohort study on cord blood folate subtypes and risk of autism spectrum disorder. Am. J. Clin. Nutr. 2020, 112, 1304-1317. [CrossRef]

97. Banka, S.; Blom, H.J.; Walter, J.; Aziz, M.; Urquhart, J.; Clouthier, C.M.; Rice, G.I.; de Brouwer, A.P.; Hilton, E.; Vassallo, G.; et al. Identification and characterization of an inborn error of metabolism caused by dihydrofolate reductase deficiency. Am. J. Hum. Genet. 2011, 88, 216-225. [CrossRef]

98. Bailey, S.W.; Ayling, J.E. The extremely slow and variable activity of dihydrofolate reductase in human liver and its implications for high folic acid intake. Proc. Natl. Acad. Sci. USA 2009, 106, 15424-15429. [CrossRef]

99. Stanislawska-Sachadyn, A.; Brown, K.S.; Mitchell, L.E.; Woodside, J.V.; Young, I.S.; Scott, J.M.; Murray, L.; Boreham, C.A.; McNulty, H.; Strain, J.J.; et al. An insertion/deletion polymorphism of the dihydrofolate reductase (DHFR) gene is associated with serum and red blood cell folate concentrations in women. Hum. Genet. 2008, 123, 289-295. [CrossRef]

100. Burdennyy, A.M.; Loginov, V.I.; Zavarykina, T.M.; Braga, E.A.; Kubatiev, A.A. The role of molecular genetic alterations in genes involved in folate and homocysteine metabolism in multifactorial diseases pathogenesis. Russ. J. Genet. 2017, 53, 528-541. [CrossRef] 
101. Ramaekers, V.T.; Sequeira, J.M.; Quadros, E.V. The basis for folinic acid treatment in neuro-psychiatric disorders. Biochimie 2016, 126, 79-90. [CrossRef]

102. Chen, M.J.; Shimada, T.; Moulton, A.D.; Cline, A.; Humphries, R.K.; Maizel, J.; Nienhuis, A.W. The functional human dihydrofolate reductase gene. J. Biol. Chem. 1984, 259, 3933-3943. [CrossRef]

103. Higgins, C.E.; Gross, S.S. Chapter 6-Tetrahydrobiopterin: An Essential Cofactor for Nitric Oxide Synthases and Amino Acid Hydroxylases. In Nitric Oxide, 2nd ed.; Ignarro, L.J., Ed.; Academic Press: San Diego, CA, USA, 2010; pp. 169-209. [CrossRef]

104. Autism Genome Project, C.; Szatmari, P.; Paterson, A.D.; Zwaigenbaum, L.; Roberts, W.; Brian, J.; Liu, X.Q.; Vincent, J.B.; Skaug, J.L.; Thompson, A.P.; et al. Mapping autism risk loci using genetic linkage and chromosomal rearrangements. Nat. Genet. 2007, 39, 319-328. [CrossRef]

105. Fellah, S.; Cheung, Y.T.; Scoggins, M.A.; Zou, P.; Sabin, N.D.; Pui, C.H.; Robison, L.L.; Hudson, M.M.; Ogg, R.J.; Krull, K.R. Brain Activity Associated With Attention Deficits Following Chemotherapy for Childhood Acute Lymphoblastic Leukemia. J. Natl. Cancer Inst. 2019, 111, 201-209. [CrossRef]

106. Zajac-Spychala, O.; Pawlak, M.; Karmelita-Katulska, K.; Pilarczyk, J.; Jonczyk-Potoczna, K.; Przepiora, A.; Derwich, K.; Wachowiak, J. Anti-leukemic treatment-induced neurotoxicity in long-term survivors of childhood acute lymphoblastic leukemia: Impact of reduced central nervous system radiotherapy and intermediate- to high-dose methotrexate. Leuk. Lymphoma 2018, 59, 2342-2351. [CrossRef]

107. Wiens, D.; DeSoto, M.C. Is High Folic Acid Intake a Risk Factor for Autism?-A Review. Brain Sci. 2017, 7, 149. [CrossRef]

108. Neggers, Y. The Relationship between Folic Acid and Risk of Autism Spectrum Disorders. Healthcare 2014, 2, 429-444. [CrossRef]

109. Plumptre, L.; Masih, S.P.; Ly, A.; Aufreiter, S.; Sohn, K.J.; Croxford, R.; Lausman, A.Y.; Berger, H.; O'Connor, D.L.; Kim, Y.I. High concentrations of folate and unmetabolized folic acid in a cohort of pregnant Canadian women and umbilical cord blood. Am. J. Clin. Nutr. 2015, 102, 848-857. [CrossRef]

110. Obeid, R.; Kirsch, S.H.; Dilmann, S.; Klein, C.; Eckert, R.; Geisel, J.; Herrmann, W. Folic acid causes higher prevalence of detectable unmetabolized folic acid in serum than B-complex: A randomized trial. Eur. J. Nutr. 2016, 55, 1021-1028. [CrossRef]

111. Lubinsky, M. An epigenetic association of malformations, adverse reproductive outcomes, and fetal origins hypothesis related effects. J. Assist. Reprod. Genet. 2018, 35, 953-964. [CrossRef]

112. Sulistyoningrum, D.; Green, T.; Palmer, D.; Sullivan, T.; Wood, S.; Makrides, M.; Skubisz, M.; Best, K.P. Study protocol for a randomised controlled trial evaluating the effect of folic acid supplementation beyond the first trimester on maternal plasma unmetabolised folic acid in late gestation. BMJ Open 2020, 10, e040416. [CrossRef]

113. Kraus, J.P.; Oliveriusova, J.; Sokolova, J.; Kraus, E.; Vlcek, C.; de Franchis, R.; Maclean, K.N.; Bao, L.; Bukovská, G.; Patterson, D.; et al. The human cystathionine $\beta$-synthase (CBS) gene: Complete sequence, alternative splicing, and polymorphisms. Genomics 1998, 52, 312-324. [CrossRef]

114. Meier, M.; Janosik, M.; Kery, V.; Kraus, J.P.; Burkhard, P. Structure of human cystathionine $\beta$-synthase: A unique pyridoxal 5'-phosphate-dependent heme protein. EMBO J. 2001, 20, 3910-3916. [CrossRef] [PubMed]

115. Blom, H.J.; Smulders, Y. Overview of homocysteine and folate metabolism. With special references to cardiovascular disease and neural tube defects. J. Inherit. Metab. Dis. 2011, 34, 75-81. [CrossRef] [PubMed]

116. Kim, J.; Kim, H.; Roh, H.; Kwon, Y. Causes of hyperhomocysteinemia and its pathological significance. Arch. Pharm. Res. 2018, 41, 372-383. [CrossRef] [PubMed]

117. Morris, A.A.; Kozich, V.; Santra, S.; Andria, G.; Ben-Omran, T.I.; Chakrapani, A.B.; Crushell, E.; Henderson, M.J.; Hochuli, M.; Huemer, M.; et al. Guidelines for the diagnosis and management of cystathionine $\beta$-synthase deficiency. J. Inherit. Metab. Dis. 2017, 40, 49-74. [CrossRef]

118. Menezo, Y.; Mares, P.; Cohen, M.; Brack, M.; Viville, S.; Elder, K. Autism, imprinting and epigenetic disorders: A metabolic syndrome linked to anomalies in homocysteine recycling starting in early life? J. Assist. Reprod. Genet. 2011, 28, 1143-1145. [CrossRef]

119. Menezo, Y.J.; Elder, K.; Dale, B. Link Between Increased Prevalence of Autism Spectrum Disorder Syndromes and Oxidative Stress, DNA Methylation, and Imprinting: The Impact of the Environment. JAMA Pediatr. 2015, 169, 1066-1067. [CrossRef]

120. James, S.J.; Cutler, P.; Melnyk, S.; Jernigan, S.; Janak, L.; Gaylor, D.W.; Neubrander, J.A. Metabolic biomarkers of increased oxidative stress and impaired methylation capacity in children with autism. Am. J. Clin. Nutr. 2004, 80, 1611-1617. [CrossRef]

121. Anderson, G.M. Autism biomarkers: Challenges, pitfalls and possibilities. J. Autism Dev. Disord. 2015, 45, 1103-1113. [CrossRef]

122. Tognazzo, S.; Gemmati, D.; Palazzo, A.; Catozzi, L.; Carandina, S.; Legnaro, A.; Tacconi, G.; Scapoli, G.L.; Zamboni, P. Prognostic role of factor XIII gene variants in nonhealing venous leg ulcers. J. Vasc. Surg. 2006, 44, 815-819. [CrossRef]

123. Singh, A.V.; Vyas, V.; Montani, E.; Cartelli, D.; Parazzoli, D.; Oldani, A.; Zeri, G.; Orioli, E.; Gemmati, D.; Zamboni, P. Investigation of in vitro cytotoxicity of the redox state of ionic iron in neuroblastoma cells. J. Neurosci. Rural. Pract. 2012, 3, 301-310. [CrossRef]

124. Golimbet, V.; Korovaitseva, G.; Abramova, L.; Kaleda, V. The 844 ins 68 polymorphism of the cystathionine $\beta$-synthase gene is associated with schizophrenia. Psychiatry Res. 2009, 170, 168-171. [CrossRef]

125. Lechpammer, M.; Tran, Y.P.; Wintermark, P.; Martinez-Cerdeno, V.; Krishnan, V.V.; Ahmed, W.; Berman, R.F.; Jensen, F.E.; Nudler, E.; Zagzag, D. Upregulation of cystathionine $\beta$-synthase and p70S6K/S6 in neonatal hypoxic ischemic brain injury. Brain Pathol. 2017, 27, 449-458. [CrossRef] [PubMed]

126. May, T.; Adesina, I.; McGillivray, J.; Rinehart, N.J. Sex differences in neurodevelopmental disorders. Curr. Opin. Neurol. 2019, 32, 622-626. [CrossRef] 
127. Piccini, P.; Montagnani, C.; de Martino, M. Gender disparity in pediatrics: A review of the current literature. Ital. J. Pediatr. 2018, 44, 1. [CrossRef]

128. Braunstein, V.L.; Peniston, N.; Perelman, A.; Cassano, M.C. The inclusion of fathers in investigations of autistic spectrum disorders. Res. Autism Spectr. Disord. 2013, 7, 8. [CrossRef]

129. Volkmar, F.R.; Szatmari, P.; Sparrow, S.S. Sex differences in pervasive developmental disorders. J. Autism Dev. Disord. 1993, 23, 579-591. [CrossRef]

130. Szatmari, P.; Liu, X.Q.; Goldberg, J.; Zwaigenbaum, L.; Paterson, A.D.; Woodbury-Smith, M.; Georgiades, S.; Duku, E.; Thompson, A. Sex differences in repetitive stereotyped behaviors in autism: Implications for genetic liability. Am. J. Med. Genet. B Neuropsychiatr. Genet. 2012, 159B, 5-12. [CrossRef]

131. Merikangas, A.K.; Almasy, L. Using the tools of genetic epidemiology to understand sex differences in neuropsychiatric disorders. Genes Brain Behav. 2020, 19, e12660. [CrossRef]

132. Szatmari, P.; Georgiades, S.; Duku, E.; Bennett, T.A.; Bryson, S.; Fombonne, E.; Mirenda, P.; Roberts, W.; Smith, I.M.; Vaillancourt, T.; et al. Developmental trajectories of symptom severity and adaptive functioning in an inception cohort of preschool children with autism spectrum disorder. JAMA Psychiatry 2015, 72, 276-283. [CrossRef]

133. Fombonne, E. Epidemiology of pervasive developmental disorders. Pediatr. Res. 2009, 65, 591-598. [CrossRef]

134. Geary, D.C. Autism in the broader context of cognitive sex differences. Proc. Natl. Acad. Sci. USA 2018, 115, $12089-12091$. [CrossRef] [PubMed]

135. Zander, E.; Sturm, H.; Bolte, S. The added value of the combined use of the Autism Diagnostic Interview-Revised and the Autism Diagnostic Observation Schedule: Diagnostic validity in a clinical Swedish sample of toddlers and young preschoolers. Autism 2015, 19, 187-199. [CrossRef] [PubMed]

136. Gray, D.E. Gender and coping: The parents of children with high functioning autism. Soc. Sci. Med. 2003, 56, 631-642. [CrossRef]

137. Lai, M.C.; Lombardo, M.V.; Auyeung, B.; Chakrabarti, B.; Baron-Cohen, S. Sex/gender differences and autism: Setting the scene for future research. J. Am. Acad. Child Adolesc. Psychiatry 2015, 54, 11-24. [CrossRef]

138. Bartley, J.J. An update on autism: Science, gender, and the law. Gend. Med. 2006, 3, 73-78. [CrossRef]

139. Burghardt, K.J.; Pilsner, J.R.; Bly, M.J.; Ellingrod, V.L. DNA methylation in schizophrenia subjects: Gender and MTHFR 677C/T genotype differences. Epigenomics 2012, 4, 261-268. [CrossRef]

140. Blumkin, E.; Levav-Rabkin, T.; Melamed, O.; Galron, D.; Golan, H.M. Gender-specific effect of Mthfr genotype and neonatal vigabatrin interaction on synaptic proteins in mouse cortex. Neuropsychopharmacology 2011, 36, 1714-1728. [CrossRef]

141. Berdasco, M.; Esteller, M. Clinical epigenetics: Seizing opportunities for translation. Nat. Rev. Genet. 2019, 20, 109-127. [CrossRef]

142. Xavier, M.J.; Roman, S.D.; Aitken, R.J.; Nixon, B. Transgenerational inheritance: How impacts to the epigenetic and genetic information of parents affect offspring health. Hum. Reprod. Update 2019, 25, 518-540. [CrossRef]

143. Yamaguchi, S.; Hong, K.; Liu, R.; Inoue, A.; Shen, L.; Zhang, K.; Zhang, Y. Dynamics of 5-methylcytosine and 5hydroxymethylcytosine during germ cell reprogramming. Cell Res. 2013, 23, 329-339. [CrossRef]

144. Mastrototaro, G.; Sessa, A. Chapter 9-Emerging Role of Epigenetics in Human Neurodevelopmental Disorders. In Epigenetics in Human Disease, 2nd ed.; Tollefsbol, T.O., Ed.; Academic Press: Cambridge, MA, USA, 2018; Volume 6, pp. $269-304$.

145. Gegenhuber, B.; Tollkuhn, J. Sex Differences in the Epigenome: A Cause or Consequence of Sexual Differentiation of the Brain? Genes 2019, 10, 432. [CrossRef] [PubMed]

146. Lister, R.; Mukamel, E.A.; Nery, J.R.; Urich, M.; Puddifoot, C.A.; Johnson, N.D.; Lucero, J.; Huang, Y.; Dwork, A.J.; Schultz, M.D.; et al. Global epigenomic reconfiguration during mammalian brain development. Science 2013, 341, 1237905. [CrossRef] [PubMed]

147. Garg, P.; Sharp, A.J. Screening for rare epigenetic variations in autism and schizophrenia. Hum. Mutat. 2019, 40, 952-961. [CrossRef]

148. Sabit, H.; Tombuloglu, H.; Rehman, S.; Almandil, N.B.; Cevik, E.; Abdel-Ghany, S.; Rashwan, S.; Abasiyanik, M.F.; Yee Waye, M.M. Gut microbiota metabolites in autistic children: An epigenetic perspective. Heliyon 2021, 7, e06105. [CrossRef]

149. Masini, E.; Loi, E.; Vega-Benedetti, A.F.; Carta, M.; Doneddu, G.; Fadda, R.; Zavattari, P. An Overview of the Main Genetic, Epigenetic and Environmental Factors Involved in Autism Spectrum Disorder Focusing on Synaptic Activity. Int. J. Mol. Sci. 2020, 21, 8290. [CrossRef]

150. Hu, V.W.; Hong, Y.; Xu, M.; Shu, H.T. Altered DNA methylation in a severe subtype of idiopathic autism: Evidence for sex differences in affected metabolic pathways. Autism 2020, 25, 887-910. [CrossRef]

151. Siu, M.T.; Goodman, S.J.; Yellan, I.; Butcher, D.T.; Jangjoo, M.; Grafodatskaya, D.; Rajendram, R.; Lou, Y.; Zhang, R.; Zhao, C.; et al. DNA Methylation of the Oxytocin Receptor Across Neurodevelopmental Disorders. J. Autism Dev. Disord. 2021. [CrossRef]

152. Banik, A.; Kandilya, D.; Ramya, S.; Stunkel, W.; Chong, Y.S.; Dheen, S.T. Maternal Factors that Induce Epigenetic Changes Contribute to Neurological Disorders in Offspring. Genes 2017, 8, 150. [CrossRef]

153. Kundakovic, M.; Jaric, I. The Epigenetic Link between Prenatal Adverse Environments and Neurodevelopmental Disorders. Genes 2017, 8, 104. [CrossRef]

154. Abdalla, H.; Yoshizawa, Y.; Hochi, S. Active demethylation of paternal genome in mammalian zygotes. J. Reprod. Dev. 2009, 55, 356-360. [CrossRef]

155. Prasoona, K.R.; Sunitha, T.; Srinadh, B.; Muni Kumari, T.; Jyothy, A. Maternal association and influence of DHFR 19 bp deletion variant predisposes foetus to anencephaly susceptibility: A family-based triad study. Biomarkers 2018, 23, 640-646. [CrossRef] 
156. Ahmed, O.G.; Shehata, G.A.; Ali, R.M.; Makboul, R.; Abd Allah, E.S.H.; Abd El-Rady, N.M. Folic acid ameliorates neonatal isolation-induced autistic like behaviors in rats: Epigenetic modifications of BDNF and GFAP promotors'. Appl. Physiol. Nutr. Metab. 2021. [CrossRef]

157. Mentch, S.J.; Locasale, J.W. One-carbon metabolism and epigenetics: Understanding the specificity. Ann. N. Y. Acad. Sci. 2016, 1363, 91-98. [CrossRef]

158. Koemans, T.S.; Kleefstra, T.; Chubak, M.C.; Stone, M.H.; Reijnders, M.R.F.; de Munnik, S.; Willemsen, M.H.; Fenckova, M.; Stumpel, C.; Bok, L.A.; et al. Functional convergence of histone methyltransferases EHMT1 and KMT2C involved in intellectual disability and autism spectrum disorder. PLoS Genet. 2017, 13, e1006864. [CrossRef]

159. Van Winkle, L.J.; Ryznar, R. One-Carbon Metabolism Regulates Embryonic Stem Cell Fate Through Epigenetic DNA and Histone Modifications: Implications for Transgenerational Metabolic Disorders in Adults. Front. Cell Dev. Biol. 2019, 7, 300. [CrossRef]

160. Mitra, I.; Huang, B.; Mousavi, N.; Ma, N.; Lamkin, M.; Yanicky, R.; Shleizer-Burko, S.; Lohmueller, K.E.; Gymrek, M. Patterns of de novo tandem repeat mutations and their role in autism. Nature 2021, 589, 246-250. [CrossRef]

161. Searles Quick, V.B.; Wang, B.; State, M.W. Leveraging large genomic datasets to illuminate the pathobiology of autism spectrum disorders. Neuropsychopharmacology 2021, 46, 55-69. [CrossRef]

162. Kim, N.; Kim, K.H.; Lim, W.J.; Kim, J.; Kim, S.A.; Yoo, H.J. Whole Exome Sequencing Identifies Novel De Novo Variants Interacting with Six Gene Networks in Autism Spectrum Disorder. Genes 2020, 12, 1. [CrossRef]

163. Emberti Gialloreti, L.; Enea, R.; Di Micco, V.; Di Giovanni, D.; Curatolo, P. Clustering Analysis Supports the Detection of Biological Processes Related to Autism Spectrum Disorder. Genes 2020, 11, 1476. [CrossRef]

164. Mesleh, A.G.; Abdulla, S.A.; El-Agnaf, O. Paving the Way toward Personalized Medicine: Current Advances and Challenges in Multi-OMICS Approach in Autism Spectrum Disorder for Biomarkers Discovery and Patient Stratification. J. Pers. Med. 2021, 11, 41. [CrossRef] [PubMed]

165. Loomes, R.; Hull, L.; Mandy, W.P.L. What Is the Male-to-Female Ratio in Autism Spectrum Disorder? A Systematic Review and Meta-Analysis. J. Am. Acad. Child Adolesc. Psychiatry 2017, 56, 466-474. [CrossRef] [PubMed]

166. Cortes, L.R.; Cisternas, C.D.; Forger, N.G. Does Gender Leave an Epigenetic Imprint on the Brain? Front. Neurosci. 2019, 13, 173. [CrossRef] [PubMed] 